\title{
The Development of the Polish Novel: Functions and Structure
}

The novel is the only major literary genre whose origins and development we have been able to watch in detail. It also seems to be the only genre whose development depended more on the customers than on the makers. Richardson, who wrote Pamela because he noticed how popular a continuous story in the form of letters could be ; Fielding, who exploited Richardson's success in his parodistic Joseph Andrews; Scott, who produced innumerable historical romances, gamely trying to match demand with supply; Dickens, who accidentally struck a gold mine with the first chapters of The Pickwick Papers; Dostoevsky, who made extensive use of the conventions of popular, sensational novels-all are typical of the way the novel evolved. In other literary forms the discrepancy between merits and rewards, creativeness and popular expectations, and originality and response has been so frequent as to become proverbial. But this is not true of the nineteenth-century novel, where it is unusual to find a writer like Stendhal, who gained his reputation only after his death.

The sociologists have a ready explanation: the rise of the novel was simultaneous with the emergence of a large middle-class readership. ${ }^{1}$ As long as this social group preserved its vigor and a certain cultural homogeneity, and as long as it formed the major part of the reading public, the development of the novel was, in a sense, a process of almost idyllic harmony between authors and readers. (That the "easy," sensational, mode-exploiting, intellectually primitive writers have been generally more popular is another matter.)

When we turn from these generalities to the Polish scene, we are faced with certain striking peculiarities. First, until the last quarter of the nineteenth century the majority of readers in Poland were not bourgeois but landed gentry. Second, the preponderance of gentry readership, which was simply a reflection of the cultural domination of this class, carried with it certain traditional attitudes. Generally speaking, these attitudes reflected a strong political involvement of literature, an interest in broad social and national affairs rather than in psychological analyses, and a feeling of civic responsibility and obligation on the part of both writers and readers. Third, the first examples of the modern novel in Poland, which date from the late eighteenth and early

1. See Q. D. Leavis, Fiction and the Reading Public (London, 1932). 
nineteenth centuries, appeared at a time of unprecedented political and ideological turmoil. With only a slight simplification we can say that the Polish novel was born at the same time that the Polish kingdom disappeared from the map of Europe. These peculiar circumstances had a marked influence on the development of the typical structure of the Polish novel. To grasp their workings and importance we have to cast a brief glance at some of the more characteristic, popular, and influential early Polish examples of the genre.

Mikołaja Doświadczyńskiego przypadki (The Adventures of M. Dośziadczynski, 1776), by the enlightened, witty bishop Ignacy Krasicki, has been unanimously regarded as the first modern Polish novel. It is a curious work, didactic but funny, combining three different elements: the novel of education, the utopian novel, and the romance of adventure. ${ }^{2}$ The narrator-hero is a nobleman who has gone through a long and involved series of formative experiences-hence the title (dośziadczenie means "experience" in Polish). Characteristically, although Krasicki was familiar with the work of the great English novelists of the century, his book resembles instead Voltaire's didactic grotesque, Candide. Krasicki's second novel, Pan Podstoli (1778), presents an elevating and rather boring picture of the ideal landowner. It was astonishingly popular, and traces of its influence can be found as far removed as in the second volume of Gogol's Dead Souls. ${ }^{3}$

After a quarter of a century, in 1805 there appeared in Warsaw Grenadier filozof, the only novel by Cyprian Godebski, a poet-soldier, who was to die heroically four years later in the defense of Warsaw against the Austrian army. This slim volume introduced several remarkable novelties. It contains the story of a soldier-wanderer (a type who was becoming all too common in Polish history), and is intensely patriotic and democratic in spirit. But it is also antimercantile and antiurban. And while Godebski used the typically romantic image of nature as untamed and passionate, he also introduced nature as a symbol of political freedom.

Konstanty Wojciechowski has provided striking statistics on the publishing output between 1800 and 1835 which demonstrate a close relation between historical events (wars, the 1830 uprising) and the production of new novels. ${ }^{4}$ The dictum inter arma silent Musae seems to apply particularly well to this genre. Between the Congress of Vienna and the 1830 national insurrection, at a time of growing political oppression, the leading pioneer of the novel in

2. It contains, by the way, the first portrait of an American in Polish literature-a Pennsylvania Quaker, simple, straightforward, fabulously rich, generous, goodhearted, but modest and reserved.

3. Julian Krzyżanowski, $W$ łwiecie romantycznym (Kraków, 1961), p. 46.

4. Konstanty Wojciechowski, Historia pozeiesci w Polsce (Lwów, 1925), pp. 84-85. 
Poland was Julian Ursyn Niemcewicz, former aide-de-camp of Kościuszko and a friend of George Washington. The most popular of his novels was Jan z Teczyna (Jan of Teczyn, 1825), the first full-fledged historical novel in Polish literature. One would expect to find here a strong influence of Walter Scott; in fact, however, both the tone and the structure of Niemcewicz's work are markedly different. The real significance of the plot and the emotional atmosphere of the action are determined not by the described past events but by the implied juxtaposition with the present. What seems on the surface to be an historical narrative of certain (partly authentic) sixteenth-century events turns out to be a story with a pointedly political message. The main analogy between the past and the present is suggested by the person of the Swedish king Eric $\mathrm{XIV}$, a notorious sadist, whose behavior is strikingly similar to the excesses of the Grand Duke Constantine, the tsar's brother and the virtual ruler of the Russian part of Poland. Trying to foil the official censorship, Niemcewicz provided his novel with detailed footnotes referring to historical sources. And though he gives several excellent and realistic descriptions of life in sixteenthcentury Poland, he often changed dates and other details to increase the number of contemporary allusions. ${ }^{5}$ He developed, perhaps for the first time, what is now called "Aesopian language"-a system of innocuous signs and expressions imbued with hidden political meanings-a device that has been frequently used in Polish literature.

Another important and influential trait of this novel was that it gave its readers a feeling of retroactive compensation. Writing about the Golden Age of Polish history and culture and concentrating on the brighter side of the past, Niemcewicz presented his contemporaries, deeply dissatisfied with the present, an attractive and cheering picture of the divided country's glorious heritage.

The tendency to idealize the past, if only because it was the past of a still independent country, became one of the most powerful factors in shaping the development of Polish literature in the first half of the nineteenth century. The example of Fryderyk Skarbek's novel Pan Starosta (Mr. Prefect, 1826) is perhaps particularly striking, since the idealized past is here, in fact, a very recent one. It is personified by the main protagonist, a simple and unprepossessing elderly gentleman, who represents old, noble virtues, contrasted with contemporary greed and hypocrisy.

In later years, after the ill-fated insurrection of $1830-31$, this tendency to idealize the past grew stronger and stronger and was carried to extremes in the work of Henryk Rzewuski. In two respects Rzewuski was quite untypical: he was an archconservative (at the time when the mainstream of Polish literature was intensely democratic), and his work contained no exhortations for a

5. J. U. Niemcewicz, Jan $z$ Tęczyna, ed. Jan Dihm (Wrocław, 1954), pp. liv, lxix. 
continued fight for national independence. Still, seen from the point of view of the structural development of the genre, his historical novel Listopad (Novem$b e r, 1846)$ is a good illustration of the prevailing tendencies. The heroes of the novel are divided into two groups, centered around two contrasted protagonists, representing opposed political and cultural attitudes. "Polonism" is pitted against foreign influence; the simple tastes of the middle gentry against aristocratic refinement and snobbery; ${ }^{6}$ religious devotion against libertinism. Whatever one thought about the author's message, it was obvious that Rzewuski had revived the past with a present-day political purpose in mind.

Among the novelists who made their debuts in the 1830s and 1840s, Józef Korzeniowski and Józef Ignacy Kraszewski were undoubtedly the most popular and influential-probably more so than any other Polish novelist before them. Korzeniowski, a professional pedagogue, gave his books a definite moralistic edge. He wrote about typical representatives of the landed gentry and about their typical social and economic problems. Although Korzeniowski cannot be called a conservative, in his novels tradition is invariably found to be valuable, and the present unstable and unreliable. His last major novel, Krewni (The Cousins, 1857), created a minor sensation: one of the heroes, a gentry member from an impoverished family, finds happiness and prosperity by becoming an artisan in a big city. To appreciate Korzeniowski's innovation, one has to remember that until then middle-class life rarely found its way into the pages of Polish novels.

Kraszewski was perhaps the most prolific nineteenth-century European writer. The exact size of his output is still unknown, but it is certain that he wrote several hundred volumes-ninety novels in the years 1873-83 alone, and besides that innumerable critical articles, historical studies, letters, and so forth. ${ }^{7} \mathrm{He}$ was more than a writer: he was an institution, and he was fully aware of it. Endowed with a considerable artistic talent, a good understanding of current social issues, and an amazing memory, he spread himself very thin, producing book after book with an almost inhuman rapidity. Accused of unevenness and of forgetting quality for the sake of quantity, he would answer that his first duties were social and political, not artistic. Indeed, at a time when there was no Polish government, no parliament, no parties, no universities, no

6. Contrasting the gentry (simple, idealistic, patriotic, and devout) and the aristocracy (power-hungry, haughty, cosmopolitan, and libertine) was a staple motif in old Polish literature and in the nineteenth-century Polish political thinking. See, for example, Seweryn Goszczyński's Król zamczyska and his memorandum for Centralizacja Tozwarzystwa Demokratycznego Polskiego of 1838.

7. The editors of an extensive "outline" of his bibliography write that "a full bibliography of this writer, perhaps the most prolific in the world, will for a long time yet remain in the sphere of wishes and dreams-if not of utopias." J. I. Kraszewski, Zarys bibliograficzny (Kraków, 1966), p. 6. 
courts, and hardly any cultural organization whatsoever, Kraszewski's work played an enormous role. He provided a partial substitute for all these institutions, essential to a national life; by the same token, he was strengthening the institutional functions of literature.

These few glimpses of the most prominent Polish novels and novelists to appear before the last quarter of the nineteenth century will have to suffice as a background for a general characterization of the development of the genre, its main tendencies, and typical patterns.

As our point of departure we may take the following description of the "social novel"-the kind of novel in which, according to Eliza Orzeszkowa, Kraszewski excelled: "It is one of its basic features that all exceptionality and extraordinariness are strictly forbidden, and that its heroes have to bear a distinct stamp of type, i.e., they have to make evident the qualities of these social groups which the author wants to portray. Collective feelings, strivings, and fortunes are stressed more than spiritual processes taking place within the individual minds. Instead of a subtle, detailed penetration into the hearts and natures of individual men, the psychological scalpel analyzes here the spirit of the whole nation, or of its large parts. Artistically, this kind of novel uses broad and bold outlines." ${ }^{\prime 8}$ This fragment could easily be used as a description of the dominant traits of the Polish novel in general. In it the element of fantasy played indeed only a minor role. ${ }^{9}$ Even when romanticism was in full swing, its heroes were usually representative types, not unique individuals; social and political issues played a much more important role than problems of individual psychology. And even such psychological problems were usually looked at from the point of view of the heroes' broader, especially national, commitments. ${ }^{10}$

Of course, we have to add some other features. National problems and considerations were generally regarded as more important than the social ones. Also, the most urgent moral issues and conflicts were usually seen as arising from national responsibilities. All this is pretty evident and follows directly from the political functions of Polish literature. Some other peculiarities, however, are not so easily noticed.

Because practically all these Polish novelists were relying upon the same system of values, developed and cherished-at least officially-by the gentry-

8. Eliza Orzeszkowa, Drugie dziesięciolecie Kraszezeskiego (1840-50, first published in 1880), reprinted in Pisma krytycznoliterackie (Wrocław, 1959), p. 196.

9. Zygmunt Szweykowski, "Rozwój powieści w Polsce: III. Powieść w latach 17761930," in Polska Akademia Umiejętności, Dzieje literatury pięknej w Polsce (Kraków, 1936), $2: 567$.

10. Cf. Maria Czartoryska's Malwina (1816) or Klementyna Hoffmanowa's Dziemik Franciszki Krasinskiej (1825). 
nobility, ${ }^{11}$ they tended to present all social and political problems as moral ones. What was against the code-the only Code-was simply immoral. Other systems of values, such as the bourgeois one, were disregarded or rejected as corrupt and debased. Fundamental conflicts, such as those between utilitarianism and the ethics of honor, were rarely mentioned. Even the so-called positivistic writers of the seventies and eighties described industrial enterprises in terms of patriotic duty and national dignity. ${ }^{12}$

Encamped within the boundaries of the nobility ethos, the novelists were apt to pay remarkably great attention to the vice of hypocrisy. A rich aristocrat who refused his daughter's hand to a chivalrous but poor nobleman, or a proud magnate who prevented his son from marrying a girl from an impoverished family, deviated from the precious rule of the szlachta's internal equality, and such actions were furiously and repeatedly attacked, bewailed, and ridiculed, along with the cases of cowardly braggarts or noblemen secretly engaged in usury.

The prevalence of types over individuals, sociology over psychology, general rules over particular circumstances; the use of historical themes as a disguise in dealing with contemporary problems; frequent resort to allegory or "Aesopian language" to elude the censor-all of these elements impregnated the Polish novel with a certain kind of intellectualism. We may call this whole attitude "aprioristic." It is manifested in the strong tendency for the main ideas -moral, ideological, political, social-which we find expressed in a novel not to be worked out on the basis of the concrete material presented but to be assumed a priori. These ideas are not conclusions from evidence but presuppositions. In other words, the novel tended to be an illustration not a discovery. This tendency was of course also reflected in the way the fictional characters were conceived. An ambitious French novelist would conceive as his goal the search for a hero representative of the moral predicament of his day. A Polish novelist, on the contrary, would start with the typical hero suggested to him by the existing situation-and then look for his hero's moral predicament. Moreover, unlike Lermontov in A Hero of Our Time, he would define both his hero and his problems in predominantly national terms.

Another common feature was also evident, rooted not in apriorism but in the concept of human nature inherent in the nobility ethos. ${ }^{13}$ In an average Polish novel the heroes were shown to be amenable to change and capable of being developed and educated-not however by discovering their "true

11. See Andrzej Zajączkowski, Gtózene elementy kultury szlacheckiej w Polsce (Wrocław, 1961).

12. Orzeszkowa offers here a particularly striking example. Cf. Nad Niemnem, 1:72 (collected ed., Warsaw, 1947): "honor itself depends sometimes on the state of our business affairs" (i.e., honor demands that we keep our business affairs in order).

13. Cf. Werner Jaeger, Paideia: The Ideals of Greek Culture, trans. Gilbert Highet, 3 vols. (New York, 1945), 1:4-32. 
essence" or through introspection and soul-searching, but only through experience, exercise of will, skillful direction from outside, by following examples and ideals.

It is obvious that this tradition imposed severe (although in most cases probably not consciously realized) artistic restrictions on any practicing novelist. These limitations were not easy to reject, since they were, as I have indicated, founded on the specific political and ideological functions of literature in Poland. The novel was a literary genre particularly well suited to perform those functions. It was more popular and structurally more flexible than any other genre. Almost any topic, sublime or lowly, distant or near, traditional or contemporary, emotional or philosophical, could be handled within its protean form. However, this very pliability made the novel in Poland submit to the formative pressures of its peculiar functions.

The leading Polish novelists at the end of the nineteenth centuryOrzeszkowa, Sienkiewicz, and Prus-developed within the boundaries of the tradition described above. All three of them, each in his or her own fashion, tried to change or expand those boundaries. None of them, however, attempted to change the basic social functions of literature in general and the novel in particular; on the contrary, they all worked consciously and persistently to strengthen and broaden those functions by broadening the popular appeal of literature and by enriching its content. Therefore it is not surprising that they have done at least as much to perpetuate the peculiar structural tradition of the Polish novel as they have to reshape it.

Orzeszkowa, the most outspokenly progressive of these three novelists, has done the least to change the traditional structure of the novel. It is significant that she considered the "social novel" the most appropriate form for tackling modern problems and educating readers. Being (in her journalism) a staunch advocate of industrialization and general economic modernization of the country, she was at the same time thoroughly immersed in the cultural tradition of the landed gentry. "Enlightened nobility" was, consciously or not, her true social ideal.

Henryk Sienkiewicz was by any account the most successful of the trio. Not only was he immensely popular-the first Polish writer to break all social barriers and appeal to the masses of the peasantry - but he seems also to have fully attained his artistic goals. His narrative skill, his uncanny ability to achieve a perfect timing of emotional effects, the formidable persuasiveness of his imagination, and, above all, his absolute mastery of language made him a writer of unequaled cultural influence. However, all the structural shackles characterized above are at work in his novels. His artistry not only makes them unobtrusive but also makes them look natural, obvious, and acceptable.

$\mathrm{He}$ has been admired, but he also has been frequently and sometimes 
vitriolically attacked. Both sides seem to find much to support their verdicts, and I cannot, and do not wish to, go over their arguments. One thing, however, is important for our present subject. Sienkiewicz has been accused many times of writing in an unrealistic fashion, of simplifying the characters of his heroes, and so on. Much of this criticism is based on a misunderstanding or, to be precise, on a misapplication of standards. We simply cannot interpret the Trilogy in terms applicable to conventional middle-class nineteenth-century realism; it was designed, executed, and has been generally understood within the artistic framework of heroic epos (although, as historians acknowledge, the general atmosphere of the time of action and most historical details have been accurately rendered). This has to be said in Sienkiewicz's defense. However, it also has to be said that Sienkiewicz has broken one of the basic conventions of such epos: that the hero dies and the story ends in lament and grief-leaving a sense of moral victory in spite of physical demise. This is precisely what gives this epos both its artistic sophistication and philosophically mature tone, what prevents it from being just a naive and sentimental praise of valor. Sienkiewicz, writing at a time of national misery and weakening of spirit, and consciously appealing to simple tastes, decided for obvious ideological reasons to end all his major works on a note of triumph and glory. ${ }^{14}$ This increased his influence, but it also had a debilitating effect on the intellectual content of his novels.

If we name Orzeszkowa the most traditional and Sienkiewicz the most successful of the three, Prus must be deemed the most ambitious. He was endowed with a keen mind and had an exalted vision of his mission as a herald of the New Age of science and reason. His best-known novel is Lalka (The Doll, 1890), which enjoys in Poland the reputation of being probably the best nineteenth-century Polish novel and also a work free to an exceptional degree of the intellectual and artistic parochialism of which Sienkiewicz is so often accused. However, with foreign readers Lalka does not seem to fare too well, and it seems to be worth while to look for the reasons.

The standard complaint about Lalka, which I have heard from my American students, is that neither the main character, Stanisław Wokulski, nor the story itself really holds together. They claim that Wokulski's emotional life seems to belong to a different man than his life as a patriotic insurgent, selfeducated naturalist, and resourceful businessman. More important, the novel's major moral and historical problems are not integrated with the descriptions of the heroes' private affairs, especially their plentiful amorous involvements.

It is interesting to notice that the analytic concepts of this criticism are

14. He followed here the example set by Tasso's Gerusalemme liberata, this dazzling exercise in heroic pageantry, immensely popular in Poland in the seventeenth century, when the action of Sienkiewicz's Trilogy takes place. 
the same as those used by Professor Zygmunt Szweykowski in his comprehensive study of Prus's life and work, the only difference being that Szweykowski values Lalka very highly. Lalka, he says, belongs to the "social novel" type: it is, more precisely, a "novel of epochs," in the tradition that goes back to Walter Scott. ${ }^{15}$ National and social motifs are here juxtaposed with emotional and personal ones; the latter are exploited toward a fuller demonstration of the former. Moreover, Szweykowski says that even the multiplicity of private-erotic motifs is subservient to the general end of "giving Lalka's plot the character of typicality." 18 To him, and apparently to the majority of Polish critics, there is nothing odd about the fact that Wokulski is shown as a unique and exceptional individual, deeply entangled in his peculiar emotional problems, and is at the same time supposed to embody (or symbolize) certain typical and general sociocultural developments in Poland in the second half of the nineteenth century. On the contrary, his psychological insights and his interest in the complexities of personal relations are seen as an artistic success, a mask of sophistication and maturity.

Lalka is undeniably the least aprioristic Polish novel of the nineteenth century. But there is also no denying that the overall structure of this novel has nothing to do with individual psychology and descriptions of numerous love involvements. It is entirely subordinated to the idea of showing a society at the moment of a deep moral and ideological crisis.

To Polish readers, who take for granted the framework of the "social novel" with political and ideological meanings hidden everywhere, Prus's preoccupation with peculiar states of consciousness and his analysis of various forms of love seem to be a daring and successful attempt at grafting the elements of the psychological novel upon the body of the social novel, and at broadening the artistic and intellectual horizons of national literature. But to a foreigner this graft does not seem to produce a living organism; he does not take the traditional formal framework for granted, and he sees Prus's integrating experiment as jumping back and forth from one convention to another. Sienkiewicz's psychological novel Bez dogmatu (Without Dogma, 1891), although undoubtedly less sophisticated intellectually and artistically inventive, was much more successful with foreign readers. (Tolstoy praised it highly.) That was not only because the subject itself was more cosmopolitan, but also because Sienkiewicz, although he concentrated on psychological and philosophical issues, did not try to overstep the boundaries, which he accepted as natural, of the "type novel." His book is not a study in individual psychology but in the psychology of character, as are Molière's comedies.

15. Zygmunt Szweykowski, Twórczosć Bolestawa Prusa (Poznań, 1947), 1:225.

16. Ibid., p. 229. 
The great realists of the late nineteenth century did not, as I have already remarked, basically change either the functions or the structure of the Polish novel. Rather they strengthened the importance of the traditional structure by fulfilling the traditional functions more successfully. Thus the legacy of Orzeszkowa, Sienkiewicz, and Prus, though richer and more complex, was essentially similar to the legacy of their predecessors. National and social responsibilities were still seen as preceding the artistic ones; the writer was first a citizen and only secondly an artist. The novel was, as before, considered a vehicle for political and ideological messages. Public problems were still considered much more important than private ones. Consequently, presentations of typical characters and situations played a more prominent role than psychological insights and analyses of personal relations. The hero's position, status, or function and his overt behavior in general were given more attention than his thoughts and personality.

In nineteenth-century West European fiction the action more often than not takes the hero from the situation of being immersed in his (frequently stifling) environment to his liberation through independence or to a realization of his essential solitude. In Polish literature the usual direction is just the opposite : it leads from isolation, selfish egocentrism, or alienation to commitment and a feeling of belonging. The Western (and characteristically middleclass) route leads to psychology; the Polish, away from it.

The role of heroines is a good illustration of the peculiarities of the Polish novel. It is characteristic of the nobility ethos that women are seen as patronesses, propagators of culture, and guardians of the purity of ideals. ${ }^{17}$ The cultural history of nineteenth-century Poland offers ample evidence that the duties of men were (ideally) seen to consist of fighting or working for the country and of caring for the family's welfare. The duties of women were understood as preserving intact the national ideals (which could become tarnished in man's everyday wrangling with hostile reality) and cultivating music, poetry, and even philosophy. ${ }^{18}$ Such a division of roles was, of course, reflected in literature-hence the number of highly idealized heroines; their "idealization" is, strange as it may sound, frequently a realistic element. Hence also the dearth of "soft" femininity and sensual eroticism : the greatest heroines of Polish literature, such as Mickiewicz's Grażna, combine both feminine and masculine functions, displaying at the moment of need virtues expected of men.

The advent of "modernism" at the end of the century brought the first wave of attacks against both the traditional function and typical structure of the Polish novel. Both the subservience of artistic to political aims and the resulting structural limitations were assailed. Nevertheless, the leading prose writer of

17. Cf. Jaeger, Paideia, 1:23.

18. See, for example, Henryk Rzewuski, Pamiatki Soplicy (1839), chapter 4. 
the time, Stefan Żeromski, operated almost exclusively within the traditional boundaries of the novel. He also succeeded in increasing the ideological appeal of fiction by introducing violently emotional tones into his short stories and novels and boldly and directly raising the most painful issues of social injustice and political oppression. It is worth noticing at this juncture that even though Zeromski was an avowed socialist, his ethical and historical ideas were evidently rooted in the gentry-nobility culture. And when he inveighed against social and economic exploitation of the masses, he focused his attention almost solely on the peasantry, rarely mentioning the urban proletariat.

The restoration of independent Poland in 1918 created a new situation in which the traditional functions of Polish literature could change. And they began to change, if only slowly. However, the Second World War and its ideologically turbulent aftermath has reinstated and reinforced those functions. Of course, it is impossible to generalize about the twentieth century in the same way as about the nineteenth: apart from the lack of perspective, we have to deal with more writers, more forms, more tendencies-and more international influences and crosscurrents. Still, it is significant that the two most representative novelists of the 1918-39 period, Maria Dąbrowska and Juliusz Kaden-Bandrowski, continued, in the main body of their work, the traditions outlined above.

The "functional enslavement" of Polish literature has been frequently bewailed by the writers themselves. But as they have protested against the limitations imposed on them by their nonartistic duties, with equal right they also should have complained about something potentially no less cripplingthe readers' habit of looking everywhere for hidden political or ideological meanings. There are many novels which obviously cannot sustain such interpretive assaults.

Numerous critics, notably Stanisław Brzozowski, castigated the selfconsoling attitude, so widespread in Polish fiction (and usually coupled with the device of "retroactive compensation") and so apparent in Sienkiewicz. Żeromski, and later Kaden, have demonstrated that it is possible to reject this attitude while still remaining in the mainstream of functional and structural tradition. Another frequent critical accusation has been that because of its functional burdens Polish literature has become parochial, untranslatable, and incomprehensible to uninitiated foreigners. Particularly common have been complaints about the primitiveness of psychology and the lack of essential, metaphysical issues in the Polish novel. A correction of these two deficiencies was one of the main concerns of writers active between the two world wars.

All those grudges and accusations are to a certain, and perhaps very large, extent justified. However, we have to recognize the tacitly assumed 
foundations of some of them. First, it is presumed that artistic and aesthetic criteria are either more important than or at least separable from the criteria of social and generally cultural merit, and that the impact made by literature as an art is more important or at least separable from its moral, mythmaking, ideological, and political importance. Second, many complaints are based upon a tacit acceptance of standards and values characteristic of middle-class culture and on the application of those standards to the product of a different type of culture based on a different set of values. Third, the accusation of a lack of concern for metaphysical problems seems to be based on the assumption that those problems must refer to something else than the direct content of our experience. Because, although it is true that there are in Polish literature few books on Death, Loneliness, Suffering, or Violence, there is no lack of books on dying, killing and being killed, on the crushing burden of individual responsibility, on solitude in prison, on friendship and betrayal, torture, extermination, and unknown graves. The whole eschatology is constantly present, although couched in concrete empirical terms-the terms given to it by national experience. (Perhaps this experiential concreteness is one reason why Polish philosophy has been so markedly positivistic.)

A certain parochialism of Polish literature is a fact, just as it is a fact that the food of the Eskimo is rather unacceptable to people living in a temperate climate. Still, the Eskimo has survived, thanks to his seal-fat diet. But the barriers in literature turn out to be surmountable, and it seems appropriate to end this essay on the exoticism of the Polish novel by quoting the case of a typically Polish writer being understood by, and in some way influencing, a typically American novelist. William Faulkner wrote to Malcolm Cowley: "The only book foreword I ever remembered was one I read when I was about sixteen [in Sienkiewicz's Pan Michael], something like, 'This book written in travail (he may have said even agony and sacrifice) for the uplifting of men's hearts.' Which I believe is the one worthwhile purpose of any book."10 And the crucial phrase in Faulkner's Nobel Prize address has a ring familiar to every Polish ear: "It is [the writer's] privilege to help man endure by lifting his heart." 20

19. Malcolm Cowley, The Faulkner-Cowley File (New York, 1966), p. 115. Cowley dates the letter November 1, 1948. The quotation from Sienkiewicz is correct almost to a word, but it comes not from the-nonexisting-preface, but from the postword to Pan Michael.

20. Frederick J. Hoffman and Olga W. Vickery, eds., William Faulkner: Three Decades of Criticism (East Lansing, 1960), p. 348. 